\title{
HIV-I host interactions: integration of large-scale datasets
} Amalio Telenti

\author{
Address: Institute of Microbiology, University Hospital Center, University of Lausanne, Bugnon 48, 1011 Lausanne, Switzerland \\ Email: amalio.telenti@chuv.ch \\ Fl000 Biology Reports 2009, I:7I (doi:I0.34I0/BI-7I) \\ The electronic version of this article is the complete one and can be found at: http://FI000.com/Reports/Biology/content/I/7I
}

\begin{abstract}
HIV-I replication and viral pathogenesis are dependent on numerous host factors. A series of recent papers apply genome-wide and large-scale approaches to map host-virus interactions and to identify host proteins capable of restricting (that is, controlling) the virus. Strategies include genome-wide association studies, small interfering RNA screens, genome-wide transcriptome profiling, proteome studies, and the assessment of the role of host-encoded microRNAs in infection. The various layers of large-scale data are brought together through meta-analytical procedures.
\end{abstract}

\section{Introduction and context}

HIV-1 research has traditionally led to or rapidly adopted new approaches, tools, and concepts from the life sciences. It is thus no surprise to witness the pace of implementation of large-scale genome approaches in the understanding of HIV-1 biology and pathogenesis. Recent years have seen the publication of genome-wide association studies, small interfering RNA (siRNA) screens, and transcriptome and proteome analyses. These approaches have a number of distinctive features: they focus more on the host than on the virus, they are large-scale and are inspired by the hope of discovery that is not a priori, and they bring into the field new researchers from different and more quantitative fields. Moreover, the appetite for novelty means that a number of increasingly available tools and techniques - such as new sequencing equipment - will rapidly contribute new layers of data.

I have purposefully used the expression 'new layers of data' rather than 'knowledge' to emphasize the parallel development of tools to visualize and integrate data and, hopefully, create a more complete view of the makings of HIV-1. Some experts have identified needs in the field and are orchestrating the joint research efforts that should bring about solutions to the enormous puzzle of host-virus interactions. The present report builds on the recent publication by Bushman and colleagues [1], evaluated in Faculty of 1000 Medicine [2].

\section{Major recent advances}

The last two and a half years have seen a large number of studies that use technical platforms to genotype the host genome at high density; now between 500,000 and 1 million single-nucleotide polymorphisms are analyzed per individual. Three publications have applied this technology to the field of HIV-1. Fellay and colleagues [3] investigated the genetic associations with the level of viral load and with rates of disease progression. They identified the major histocompatibility complex (MHC) region in chromosome 6 as the main contributor to HIV1 control. Two later studies confirmed these findings $[4,5]$. Currently, the field faces two challenges: (a) how to identify the exact contributors to viral control within the MHC, a region that contains the classical HLA genes as well as other genes involved in inflammation and immunity, and (b) how to bring the published and additional follow-up studies into a joint study to complete the assessment of the role of common human variation in HIV-1 disease.

Four siRNA screens have been reported in the last year and a half [6-9]. These studies used transfected libraries of siRNA, or stably transduced short hairpin RNAs (shRNAs), to knock down expression of more than 20,000 genes, followed by infection/transduction of the cells by HIV. Combined, the three siRNA studies identified more than 800 genes as being possibly 
relevant for HIV replication; only 34 genes were shared by two or more screens. The more recent study using shRNAs to stably silence Jurkat $\mathrm{T}$ cells had only six genes shared with the other studies [9]. In addition, the study design favored the identification of genes that supported HIV replication; there are no data on genes that, when knocked down, lead to increased viral replication (that is, restriction factors).

There have been a number of transcriptome studies in HIV-1 target cells $\left(\mathrm{CD}^{+}{ }^{+} \mathrm{T}\right.$ cells, monocytes/macrophages), in non-targets such as natural killer cells and $\mathrm{B}$ cells, and in dendritic cells and total peripheral blood mononuclear cells (reviewed in [10]) [11-13]. Transcriptome analyses of cell lines transfected with individual viral proteins or mutant viruses have also been reported. These studies provide insight into gene expression changes associated with virus replication and persistence. Studies are limited by the number of genes interrogated or by the number of individuals investigated. However, more recent work is bringing to the in vivo setting a more dynamic measure of the transcriptome response to infection in models of pathogenic and non-pathogenic primate infection $[14,15]$ as well as in human infection [16].

RNA interference (RNAi) represents a vital component of the innate anti-viral immune response in plants and invertebrate animals. It also serves as a gene regulation mechanism that is triggered by the expression of microRNA (miRNA) molecules. Understanding the role of cellular miRNAs in the defense against viral infection in mammalian organisms and the influence of viral replication on the abundance and distribution of miRNAs within the host cell is a highly relevant research question. Recent work highlights the role of miRNAs in restriction of HIV-1 infection [17-19]. Triboulet and colleagues [17] reported a role of Drosha and Dicer in human cell defense against HIV-1. miRNAs act both through direct targeting of the $3^{\prime}$ untranslated region of HIV-1 $[18,19]$ and indirectly through modulation of the cellular environment [17]. Huang and colleagues [18] identified miR-28, miR-125b, miR-150, miR-223, and miR-382 as contributing to HIV-1 latency in quiescent CD4 T cells. Wang and colleagues [19] identified miR-28, miR-150, miR-223, and miR-382 as possibly protecting monocytes/macrophages from HIV-1 infection. Three recent papers assessed the involvement of miRNA in controlling HIV-1 replication: Chable-Bessia et al. [20] showed that RNAi effectors repress HIV-1 replication through HIV-1 mRNA targeting to processing bodies and translational inhibition, and Ahluwalia et al. [21] and Nathans et al. [22] evaluated the direct targeting of HIV-1 mRNA by cellular miR-29a. A recent report presented the
miRNA profile in peripheral mononuclear cells from 36 HIV-1-seropositive individuals and compared the profile with that of 12 seronegative subjects [23].

Proteome studies have also been reported in recent times in the field of HIV-1. Analysis of infected T cells by twodimensional in-gel electrophoresis detected 15\% of 2,000 protein spots as differentially expressed at peak infection [24]. Analysis of 3,200 proteins using liquid chromatography-mass spectrometry coupled with stable isotope labeling identified $21 \%$ of proteins as differentially expressed upon infection [25]. Biological pathways included ubiquitination, nucleocytoplasmic transport, cell cycle progression, and the citrate cycle. The latter study also identified changes in the abundance of proteins with known interactions with HIV-1 viral proteins [25]. The incorporation of host proteins to viral particles has been investigated in the past [26]. The National Center for Biotechnology Information maintains a HIV-host protein interaction database $[27,28]$. The National Institutes of Health has also committed to a large effort on HIV structural biology by the funding of three centers that are establishing a comprehensive structural picture of interactions between HIV viral proteins and intracellular host molecules and applying new computational and functional methods for analyzing virus/host complexes (the Center for the Structural

\section{Figure I. Genome-wide and large-scale cellular studies published since 2007 in the field of HIV}

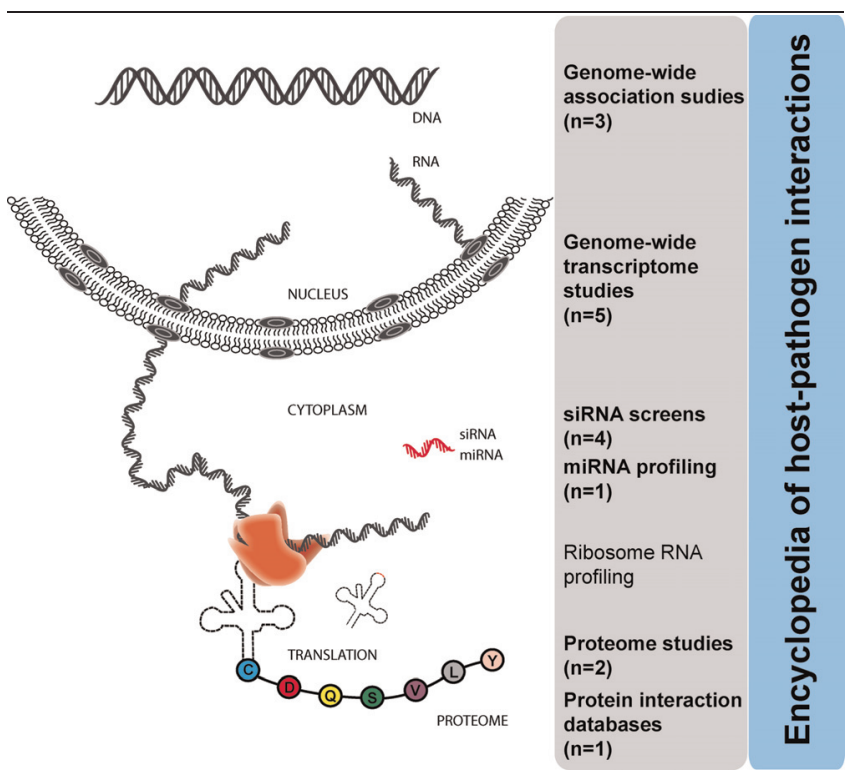

The number of studies is in parenthesis. Diverse sets of results and data are compiled in an encyclopedia of overlaps between studies [32]. This approach serves to identify networks used by HIV-I to support its replication. miRNA, microRNA; siRNA, short interfering RNA. 
Biology of Cellular Host Elements in Egress, Trafficking, and Assembly of HIV [29], the University of California San Francisco and Berkeley HIV Accessory and Regulatory Complexes Center [30], and the Pittsburgh Center for HIV Protein Interactions [31]).

Studies such as those discussed above lead naturally to the possibility of cross-evaluation and validation (Figure 1). This effort, spearheaded by Bushman and colleagues [1], used meta-analytical procedures to assess nine genome-wide studies. While pairwise comparisons of the studies resulted in modest overlaps, data analyses in the context of cellular networks and subsystems led to the identification of at least 11 densely connected clusters. These clusters, enriched for proteins identified in multiple separate screens, specify cellular subsystems associated with HIV replication: the proteasome, subunits of RNA polymerase II and associated factors, the mediator complex, the Tat activation machinery, RNAbinding and -splicing proteins, and the BiP/GRP78/ HSPA5 and CCT chaperones. The study went one additional step to organize data in an 'encyclopedia' of host factors assisting HIV replication [32]. The growing need for analyzing layers of data in the genomic context has also led to the development of 'viewers'. These are web-based tools designed for visualization of large-scale genetic and genomic data, allowing the aggregation or intersection of diverse data tracks $[33,34]$.

\section{Future directions}

Novel technology and the accumulation of genome data across species will contribute additional layers to the analyses. Examining intra- and inter-species genome data under the principles of comparative and evolutionary genomics gives investigators the potential to map genes under positive selective pressure due to pathogens. Chromatin immunoprecipitation combined with deep sequencing or with microarrays will provide more quantitative data of mRNA expression, on small noncoding RNAs, and from experiments on epigenetic reprogramming due to infection [35]. Particularly attractive techniques are those using ribosome profiling to generate precise quantitative data on the precise mRNA that is being translated - a closer surrogate of protein expression than that afforded by conventional transcriptome profiles [36]. Eventually, integration of data will complement or guide experiments designed to capture large-scale data in cycles of experimental perturbation - the core definition of systems biology.

\section{Abbreviations}

BiP, binding immunoglobulin protein (also called GRP78); CCT, chaperonin containing $\mathrm{T}$ complex protein 1 (TCP-1); GRP78, glucose-regulated protein 78;
HSPA5, heat shock protein 5; MHC, major histocompatibility complex; miRNA, microRNA; RNAi, RNA interference; shRNA, short hairpin RNA; siRNA, small interfering RNA.

\section{Competing interests}

The author declares that he has no competing interests.

\section{Acknowledgments}

This work was supported by the Swiss National Science Foundation. I thank Angela Ciuffi and Millan Ortiz for their input.

\section{References}

I. Bushman FD, Malani N, Fernandes J, D'Orso I, Cagney G, Diamond TL, Zhou H, Hazuda DJ, Espeseth AS, Konig R, Bandyopadhyay S, Ideker T, Goff SP, Krogan NJ, Frankel AD, Young JA, Chanda SK: Host cell factors in HIV replication: meta-analysis of genome-wide studies. PLoS Pathog 2009, 5: el000437.

\section{FI000 Factor 6.0 Must Read}

Evaluated by Amalio Telenti 08 Jun 2009

2. Telenti A: Evaluation of: Bushman FD, Malani N, Fernandes J, D'Orso I, Cagney G, Diamond TL, Zhou H, Hazuda DJ, Espeseth AS, Konig R, Bandyopadhyay S, Ideker T, Goff SP, Krogan NJ, Frankel AD, Young JA, Chanda SK: Host cell factors in HIV replication: meta-analysis of genome-wide studies. PLoS Pathog 2009, 5:e 1000437.

Faculty of 1000 Medicine, 8 Jun 2009

3. Fellay J, Shianna KV, Ge D, Colombo S, Ledergerber B, Weale ME, Zhang K, Gumbs C, Castagna A, Cossarizza A, Cozzi-Lepri A, De Luca, Easterbrook PJ, Francioli P, Mallal S, Martinez-Picado J, Miro JM, Obel N, Smith JP, Wyniger J, Descombes P, Antonarakis SE, Letvin NL, McMichael A, Haynes BF, Telenti A, Goldstein DB: A whole-genome association study of major determinants for host control of HIV-I. Science 2007, 3 I 7:944-7.

4. Limou S, Le Clerc S, Coulonges C, Carpentier W, Dina C, Delaneau O, Labib T, Taing L, Sladek R, Deveau C, Ratsimandresy $R$, Montes $M$, Spadoni JL, Lelièvre JD, Lévy $Y$, Therwath A, Schächter F, Matsuda F, Gut I, Froguel P, Delfraissy JF, Hercberg S, Zagury JF: ANRS Genomic Group: Genomewide association study of an AIDS-nonprogression cohort emphasizes the role played by HLA genes (ANRS Genomewide Association Study 02). J Infect Dis 2009, 199:419-26.

5. Dalmasso C, Carpentier W, Meyer L, Rouzioux C, Goujard C, Chaix ML, Lambotte O, Avettand-Fenoel V, Le Clerc S, de Senneville LD, Deveau C, Boufassa F, Debré P, Delfraissy JF, Broet P, Theodorou I: ANRS Genome Wide Association OI: Distinct genetic loci control plasma HIV-RNA and cellular HIV-DNA levels in HIV-I infection: the ANRS Genome Wide Association 01 study. PLoS One 2008, 3:e3907.

6. Brass AL, Dykxhoorn DM, Benita Y, Yan N, Engelman A, Xavier RJ, Lieberman J, Elledge SJ: Identification of host proteins required for HIV infection through a functional genomic screen. Science 2008, 3 19:921-6

FI000 Factor 10.I Exceptional

Evaluated by Fritz Eckstein 16 Jan 2008, James Crowe 28 Jan 2008, Alan Landay 03 Mar 2008, Winston Hide 27 Mar 2008

7. Konig R, Zhou $Y$, Elleder D, Diamond TL, Bonamy GM, Irelan JT, Chiang CY, Tu BP, De Jesus PD, Lilley CE, Seidel S, Opaluch AM, Caldwell JS, Weitzman MD, Kuhen KL, Bandyopadhyay S, Ideker T, Orth AP, Miraglia LJ, Bushman FD, Young JA, Chanda SK: Global 
analysis of host-pathogen interactions that regulate earlystage HIV-I replication. Cell 2008, I35:49-60.

FI000 Factor 6.0 Must Read

Evaluated by Victor Nizet 07 May 2009

8. Zhou H, Xu M, Huang Q, Gates AT, Zhang XD, Castle JC, Stec E, Ferrer M, Strulovici B, Hazuda DJ, Espeseth AS: Genome-scale RNAi screen for host factors required for HIV replication. Cell Host Microbe 2008, 4:495-504.

FI000 Factor 3.0 Recommended

Evaluated by Carolyn Coyne 13 Jan 2009

9. Yeung ML, Houzet L, Yedavalli VS, Jeang KT: A genome-wide short hairpin RNA (shRNA) screening of jurkat T-cells for human proteins contributory to productive HIV-I replication. J Biol Chem 2009, 284:19463-73.

10. Giri MS, Nebozhyn M, Showe L, Montaner LJ: Microarray data on gene modulation by HIV-I in immune cells: 2000-2006. J Leukoc Biol 2006, 80: 103I-43.

II. Sedaghat AR, German J, Teslovich TM, Cofrancesco J Jr, Jie CC, Talbot CC Jr, Siliciano RF: Chronic CD4 ${ }^{+}$T-cell activation and depletion in human immunodeficiency virus type I infection: type I interferon-mediated disruption of T-cell dynamics. J Virol 2008, 82: 1870-83.

12. Hyrcza MD, Kovacs C, Loutfy M, Halpenny R, Heisler L, Yang S, Wilkins $O$, Ostrowski M, Der SD: Distinct transcriptional profiles in ex vivo CD4+ and CD8+ $T$ cells are established early in human immunodeficiency virus type I infection and are characterized by a chronic interferon response as well as extensive transcriptional changes in CD8+ T cells. J Virol 2007, 8I:3477-86.

13. Giri MS, Nebozyhn M, Raymond A, Gekonge B, Hancock A, Creer S, Nicols C, Yousef M, Foulkes AS, Mounzer K, Shull J, Silvestri G, Kostman J, Collman RG, Showe L, Montaner LJ: Circulating monocytes in HIV-I-infected viremic subjects exhibit an antiapoptosis gene signature and virus- and host-mediated apoptosis resistance. J Immunol 2009, I 82:4459-70.

14. Mandl JN, Barry AP, Vanderford TH, Kozyr N, Chavan R, Klucking S, Barrat FJ, Coffman RL, Staprans SI, Feinberg MB: Divergent TLR7 and TLR9 signaling and type I interferon production distinguish pathogenic and nonpathogenic AIDS virus infections. Nat Med 2008, I4:1077-87.

FI000 Factor 6.4 Must Read

Evaluated by Grant McFadden 16 Oct 2008, Xiaojing Ma 29 Oct 2008

15. Lederer S, Favre D, Walters KA, Proll S, Kanwar B, Kasakow Z, Baskin CR, Palermo R, McCune JM, Katze MG: Transcriptional profiling in pathogenic and non-pathogenic SIV infections reveals significant distinctions in kinetics and tissue compartmentalization. PLoS Pathog 2009, 5:el000296.

FI000 Factor 3.0 Recommended

Evaluated by Amalio Telenti 19 Mar 2009

16. Li Q, Smith AJ, Schacker TW, Carlis JV, Duan L, Reilly CS, Haase AT: Microarray analysis of lymphatic tissue reveals stage-specific, gene expression signatures in HIV-I infection. J Immunol 2009, 183:1975-82.

17. Triboulet R, Mari B, Lin YL, Chable-Bessia C, Bennasser $Y$, Lebrigand K, Cardinaud B, Maurin T, Barbry P, Baillat V, Reynes J, Corbeau $P$, Jeang KT, Benkirane M: Suppression of microRNAsilencing pathway by HIV-I during virus replication. Science 2007, 3 15:1579-82

FI000 Factor 6.4 Must Read

Evaluated by Fritz Eckstein 06 Mar 2007, Michael Kiebler 18 Apr 2007

18. Huang J, Wang F, Argyris E, Chen K, Liang Z, Tian H, Huang W, Squires $\mathrm{K}$, Verlinghieri $\mathrm{G}$, Zhang $\mathrm{H}$ : Cellular microRNAs contribute to HIV-I latency in resting primary CD4+ T lymphocytes. Nat Med 2007, I3:124I-7.
19. Wang X, Ye L, Hou W, Zhou Y, Wang Y], Metzger DS, Ho WZ: Cellular microRNA expression correlates with susceptibility of monocytes/macrophages to HIV-I infection. Blood 2008, I | 3:67|-4.

20. Chable-Bessia C, Meziane O, Latreille D, Triboulet R, Zamborlini A Wagschal A, Jacquet JM, Reynes J, Levy Y, Saib A, Bennasser Y, Benkirane M: Suppression of HIV-I replication by microRNA effectors. Retrovirology 2009, 6:26.

21. Ahluwalia JK, Khan SZ, Soni K, Rawat P, Gupta A, Hariharan M, Scaria V, Lalwani M, Pillai B, Mitra D, Brahmachari SK: Human cellular microRNA hsa-miR-29a interferes with viral nef protein expression and HIV-I replication. Retrovirology 2008, 5: I I7.

22. Nathans R, Chu CY, Serquina AK, Lu CC, Cao H, Rana TM: Cellular microRNA and $P$ bodies modulate host-HIV-I interactions. Mol Cell 2009, 34:696-709.

23. Houzet L, Yeung ML, de LV, Desai D, Smith SM, Jeang KT: MicroRNA profile changes in human immunodeficiency virus type I (HIVI) seropositive individuals. Retrovirology 2008, 5: 118.

24. Ringrose JH, Jeeninga RE, Berkhout B, Speijer D: Proteomic studies reveal coordinated changes in T-cell expression patterns upon infection with human immunodeficiency virus type $I$. J Virol 2008, 82:4320-30.

25. Chan EY, Qian WJ, Diamond DL, Liu T, Gritsenko MA, Monroe ME, Camp DG, Smith RD, Katze MG: Quantitative analysis of human immunodeficiency virus type I-infected CD4+ cell proteome: dysregulated cell cycle progression and nuclear transport coincide with robust virus production. J Virol 2007, 8 I:757I-83.

26. Chertova E, Chertov O, Coren LV, Roser JD, Trubey CM, Bess JWJr, Sowder RC, Barsov E, Hood BL, Fisher RJ, Nagashima K, Conrads TP, Veenstra TD, Lifson JD, Ott DE: Proteomic and biochemical analysis of purified human immunodeficiency virus type I produced from infected monocyte-derived macrophages. J Virol 2006, 80:9039-52.

27. HIV-I, Human Protein Interaction Database: National Institute of Allergy \& Infectious Diseases. [http://www.ncbi. nlm.nih.gov/RefSeq/HIVInteractions]

28. Fu W, Sanders-Beer BE, Katz KS, Maglott DR, Pruitt KD, Ptak RG: Human immunodeficiency virus type $I$, human protein interaction database at NCBI. Nucleic Acids Res 2009, 37:D417D422.

29. Center for the Structural Biology of Cellular Host Elements in Egress, Trafficking, and Assembly of HIV (CHEETAH) homepage. [http://cheetah.biochem.utah.edu]

30. The HARC Center homepage. A Collaborative Research Center at UCSF and Berkeley for HIV Accessory and Regulatory Complexes. [http://harc.ucsf.edu]

3I. University of Pittsburgh. Center for HIV Protein Interactions homepage. [http://www2.structbio.pitt.edu/hivppi]

32. University of Pennsylvania. Bushman Lab - hostpathogen.org. Overlap among genome-wide studies of HIV infection. [http:// www.hostpathogen.org]

33. Ge D, Zhang K, Need AC, Martin O, Fellay J, Urban T], Telenti A, Goldstein DB: WGAViewer: software for genomic annotation of whole genome association studies. Genome Res 2008, 18:640-3.

34. Martin O, Valsesia A, Telenti A, Xenarios I, Stevenson B: AssociationViewer: a scalable and integrated software tool for visualization of large-scale variation data in genomic context. Bioinformatics 2009, 25:662-3.

35. Ferrari R, Pellegrini M, Horwitz GA, Xie W, Berk AJ, Kurdistani SK: Epigenetic reprogramming by adenovirus ela. Science 2008 , 321 : 1086-8.

36. Ingolia NT, Ghaemmaghami S, Newman JR, Weissman JS: Genomewide analysis in vivo of translation with nucleotide resolution using ribosome profiling. Science 2009, 324:218-23.

FI000 Factor 10.5 Exceptional

Evaluated by Arlen Johnson 18 Feb 2009, Koreaki Ito 05 Mar 2009, Hunter Fraser 03 Apr 2009, Matthew Sachs 28 Apr 2009, Brad Bernstein 18 Aug 2009 